\title{
Activity of Alzheimer's $Y$-secretase is linked to changes of interferon-induced transmembrane proteins (IFITM) in innate immunity
}

\author{
Annie Y. Yao and Riqiang Yan * (1)
}

\begin{abstract}
The activity of $\gamma$-secretase is critical to the pathogenesis of Alzheimer's disease (AD). How its activity is regulated is intriguing and highly important for any $A D$ therapy that focuses on reduction of toxic amyloid peptides and amyloid deposition in patients. Recently, interferon-induced transmembrane protein 3 (IFITM3) has been identified as a novel regulator of $y$-secretase through a specific interaction. This commentary highlights this exciting study and provides an updated link of $\gamma$-secretase activity to innate immunity through IFITM3.
\end{abstract}

Keywords: $\Gamma$-secretase, Presenilin, Nicastrin, Interferon-induced transmembrane protein, IFITM3, Innate immunity, Photo-crosslinking, Amyloid plaques, Alzheimer's disease

Immune activity has long been linked to Alzheimer's disease $(\mathrm{AD})$ pathology, but whether it is beneficial and detrimental to $\mathrm{AD}$ progression has stirred a great deal of debate $[7,12]$. The heat of this debate has not ebbed in recent years; rather, the premise of neuroinflammation in $\mathrm{AD}$ pathogenesis has become increasingly recognized due to growing evidence that risk genes for late onset of $\mathrm{AD}$ are predominantly expressed by microglia [11, 33]. Of the $\mathrm{AD}$ risk loci identified by genomic methods, over $50 \%$ of validated gene variants are implicated in innate immune and microglial functions, including the top 2 AD risk genes, APOE and TREM2 [14, 36]. Epigenomic analysis shows that AD GWAS loci are preferentially enriched in enhancer sequences involved in innate immune processes $[21,22]$. Intriguingly, single cell profiling of human and $\mathrm{AD}$ mouse brains has revealed disease associated microglia (DAM) with unique transcriptomic profiles that localize near amyloid plaques $[20,26]$, while

\footnotetext{
* Correspondence: riyan@uchc.edu

Department of Neuroscience, University of Connecticut Health, Farmington, CT, USA
}

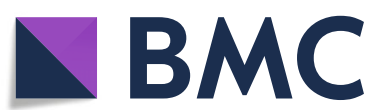

(c) The Author(s). 2020 Open Access This article is licensed under a Creative Commons Attribution 4.0 International License, which permits use, sharing, adaptation, distribution and reproduction in any medium or format, as long as you give appropriate credit to the original author(s) and the source, provide a link to the Creative Commons licence, and indicate if changes were made. The images or other third party material in this article are included in the article's Creative Commons licence, unless indicated otherwise in a credit line to the material. If material is not included in the article's Creative Commons licence and your intended use is not permitted by statutory regulation or exceeds the permitted use, you will need to obtain permission directly from the copyright holder. To view a copy of this licence, visit http://creativecommons.org/licenses/by/4.0/ The Creative Commons Public Domain Dedication waiver (http://creativecommons.org/publicdomain/zero/1.0/) applies to the data made available in this article, unless otherwise stated in a credit line to the data.

other studies highlight how dysfunctional microglia, with impaired chemotactic and phagocytic functions, result in increased $\mathrm{A} \beta$ deposition in the $\mathrm{AD}$ brain [1]. These emerging evidence emphasize how microglia, as members of the innate immune system, serve a central role in Alzheimer's neurodegeneration.

Amyloid- $\beta(A \beta)$, considered a primary cause of $A D$, may function as an antimicrobial peptide (AMP) [5, 37], and thus may play a functional role in the innate immune system. Infection from a variety of pathogens, including Chlamydia pneumoniae [4, 23], Herpes simplex virus [9], pseudorabies virus [39], Toxoplasma gondii [41] and Porphyromonas gingivalis [17], leads to increased $A \beta$ production in the brain, suggesting that bacterial and viral infections in human and animal models can shift the processing of amyloid precursor protein (APP) toward the amyloidogenic pathway, resulting in increased rates of $A \beta$ production and deposition. This increased $A \beta$ production is perhaps a defense against invading pathogens. Indeed, $A \beta$ are shown to possess antimicrobial activity against many bacterial and fungal 
pathogens as well as viruses $[13,27]$. The antimicrobial activity of $A \beta$ species may partly be due to its capacity to form fibrils, which can insert into cell membranes to permeabilize microbes, leading to their death. $A \beta$ fibrils can capture and perforate microbes with its hairpin loop, while aggregates of $A \beta$ may immobilize microbes in a manner similar to neutrophil extracellular traps (NETs) [6]. How $A \beta$ production is coordinated in such an elegant immune response remains an outstanding question in the field. Furthermore, the consequences of pathogenstimulated $\mathrm{A} \beta$ production on the risk of developing $\mathrm{AD}$ have yet to be fully elucidated.

In a recent study published by the Li lab in Nature, an innate defense is shown to stimulate $A \beta$ production, thus increasing $A D$ risk [16]. By using the $\gamma$-secretase modulator (GSM) E2012-BPyne, Hur and colleagues conducted photo-crosslinking experiments and identified interferon (IFN)-induced transmembrane protein 3 (IFIT M3) as an authentic interaction protein of $\gamma$-secretase. IFITM3 is a member of the IFITMs, a protein family that was first discovered as interferon-induced genes in human neuroblastoma cells $[2,35]$. This family has five members in the human and seven members in the rodent; homologous IFITM members are evolutionally conserved and distinguished by the presence of a canonical CD225 domain, made up of two hydrophobic membrane binding sequences separated by a highly conserved cytosolic loop. This di-spanning CD225 domain resembles the reticulon homolog domain [34], and embeds IFITMs on the lipid bilayer. Likely found on the membrane, IFITM3 interacts with $\gamma$-secretase, a protease complex known to have four multi-spanning transmembrane proteins comprised of presenilin-1 (PS1), presenilin enhancer 2, anterior pharynx defective 1 , and nicastrin (NCT). Consistent with its original discovery, IFITMs are found to limit virus infection or replication in a variety of vertebrates $[2,24,32]$, positing a possible evolutionarily significant role in host immunity across species. IFITMs block viral infection by interacting with nearby IFITMs and/or other transmembrane proteins, thereby reducing host membrane fluidity at the sites of viral fusion and preventing viral fusion pore formation.

Although IFITM proteins can play a known role in innate antiviral and adaptive immunity, virus restriction by individual IFITMs depends on cell type and intracellular localization. For example, IFITM1 is localized on the cell surface and early endosomes, and restricts HIV infection at these sites. Immunofluorescence and live-cell imaging studies reveal cellular localization of IFITM2 and 3 primarily to early and late endocytic vesicles and lysosomes $[2,8,31]$. Studies with influenza A virus in host cells suggest that IFITM2 and 3 restrict the virus entry or fusion at these sites through $\mathrm{pH}$-dependent changes in conformation of envelope glycoproteins [8, 10, 19]. A recent study has shown that IFITM3 directly engages incoming viral particles and enhances the viral trafficking from endosomes to lysosomes [38]. This is consistent with the ability of IFITM3 to limit the entry of a wide range of primarily enveloped viruses into host cells.

Expression of IFITMs is not always dependent on interferon induction, since high levels of constitutivelyexpressed IFITMs are found in many cell types [2]. Constitutive non-IFN-activated expression of IFITMs maintain persistent antiviral status against a panel of viruses. In human embryonic stem cells, constitutive expression of IFITM3 likely confers intrinsic antiviral activity [43]. IFITMs constitutively expressed by primary $\mathrm{CD}^{+} \mathrm{T}$ cells and respiratory dendritic cells may be directly involved in adaptive immunity [42]. This unique expression profile suggests a need to ensure proper function of IFITMs in certain tissues or cell types to counteract pathogenic insults.

In the context of $\mathrm{AD}$, the role of IFITM3 drew focus on an innate immune rather than an adaptive immune process [16]. Hur and colleagues discovered that $\gamma$ secretase activity correlates with increased IFITM3 levels. E2012-BPyne-labeled IFITM3 was significantly reduced in PS1 and PS2 double knockout mice compared to wild-type mice. This PS-dependent crosslink of IFIT $\mathrm{M} 3$ to the $\gamma$-secretase complex is not due to a reduction of IFITM3 mRNA levels, but rather more likely related to post-translational stability of the complex.

The authors found that IFITM3 binds directly to the active $\gamma$-secretase complex near its active site and reduces $\gamma$ secretase activity for the production of $A \beta_{40}$ and $A \beta_{42}$. IFITM3 knockdown by siRNA led to reduced $\gamma$-secretase activity, as measured by a reduced production of $A \beta_{40}$ and $A \beta_{42}$. In $5 x F A D$ transgenic mice, which express five familial $\mathrm{AD}$ mutations and recapitulate features of $\mathrm{AD}$ amyloid pathology [28], IFITM3 levels increased with age, whereas PS1 and NCT levels remained relatively constant. This increase is perhaps related to altered cellular expression profiles and localization: the authors found higher IFITM3 expression in GFAP-labeled astrocytes and IBA1-labeled microglia in the $5 \mathrm{xFAD}$ mouse brain as compared to agematched wild-type littermates, in which IFITM3 expression is primarily detected within the meninges and blood vessels. One may speculate that either gliosis in response to amyloid deposition, or FAD mutations, play a role in the increased glial IFITM3 expression. The authors show that Ifitm $^{-/-}$mice had comparable $\gamma$-secretase complex levels compared to controls, while $\gamma$-secretase activity for generating $A \beta_{40}$ and $A \beta_{42}$ was reduced. Consistently, the number of $\mathrm{A} \beta$ plaques in $5 \mathrm{xFAD} / \mathrm{Ifitm}^{-/-}$transgenic mice was also reduced.

Aging is the biggest risk factor for AD. Aging can also induce type I IFN expression, which can thereby modulate brain function [3]. Viral infection in human brains 
can alter the cytokine profiles produced by microglia [25]. Not surprisingly, IFN $\gamma$ has been explored for its role in the pathogenesis of $\mathrm{AD}$ through modulation of neuroinflammation $[26,30,40]$. In mouse primary neurons treated with IFN $\gamma$ or IFN $\alpha$ (a type I IFN), expression of IFITM3 was increased as expected, even as there was no change in the levels of NCT or PS1. Increased IFITM3 levels alone were sufficient to increase the $\gamma$ secretase activity as evidenced by higher secreted levels of $A \beta_{40}$ and $A \beta_{42}$. More importantly, elevated IFITM3 levels are evident in a subpopulation of human patients with late-onset Alzheimer's disease (LOAD), indicating its pathophysiological relevance to $\mathrm{AD}$. Consistent with mouse and in vitro assays, human tissues with high IFIT M3 levels also produced more $A \beta_{40}$ and $A \beta_{42}$.

These findings are important, as they directly link $A \beta$ production with innate immunity and neuroinflammation in a novel way. While the prevailing view is that $A \beta$ triggers a cascade of pathological gliosis and neuroinflammation $[15,18]$, Hur and colleagues have provided compelling evidence of how neuroinflammation may also activate toxic $A \beta$ generation. Of note, it has been previously shown that lipopolysaccharide, prostaglandin $E 2$, and pro-inflammatory cytokines like IL-1 $\beta$ can enhance $A \beta$ accumulation by impairing microglial phagocytosis and clearance of $A \beta$ [29]. However, this paper provides a direct link between $A \beta$ production and aggregation by identifying IFITM3 as a $\gamma$-secretase modulatory protein associated with aging and AD. Furthermore, this work is also the first to demonstrate how $A \beta$ has a physiological function as an AMP through the action of IFITM3. Targeting IFITM3 should be explored as an AD therapeutic strategy for reducing amyloid deposition. In particular, the subpopulation of LOAD patients exhibiting high levels of IFITM3 expression and activity, which strongly correlate with $\gamma$-secretase activity, may be the most suitable demographic for clinical trials of IFITM3 inhibitors. For the same reason, IFITM3 may well be developed as a biomarker to identify LOAD patients. Taken together, more research on IFITM3 and innate immunity for applications in translational $\mathrm{AD}$ therapeutics is warranted. Further study should also focus on optimizing or fine tuning the therapeutic inhibition on IFITM3, in order to avoid undesirable side effects relating to its beneficial effects on innate immunity.

\section{Conclusion}

The activity of $\gamma$-secretase can be regulated through the disruption of interaction between IFITM3 and components of $\gamma$-secretase complex.

\section{Abbreviations}

AD: Alzheimer's disease; APP: Amyloid precursor protein; A $\beta$ : amyloid- $\beta$ peptide; AMP: Antimicrobial peptide; DAM: Disease associated microglia; GFAP: Glial fibrillary acidic proteinGSM, $\gamma$-secretase modulator; IBA: Ionized calcium-binding adaptor molecule 1; IFN: Interferon; IFITM: FADfamilial AD, interferon-induced transmembrane protein; LOAD: Late-onset Alzheimer's disease; NCT: Nicastrin, NETs, neutrophil extracellular traps; PS1: Presenilin 1

\section{Acknowledgements}

RY is supported by NIH grants (AG025493, NS074256, RFAG058261 and AG046929. All authors declare no conflict interests in this study.

\section{Authors' contributions}

Both Yao and Yan wrote this manuscript. All authors read and approved the final manuscript.

\section{Authors' information}

Ms. Annie Y Yao is an MD/PHD student and Dr. Riqiang Yan is a professor of Neuroscience.

\section{Funding}

R Yan is funded by NIH grants (AG025493, NS074256, RFAG058261 and AG046929.

\section{Availability of data and materials \\ Not applicable.}

Ethics approval and consent to participate

Not applicable

\section{Consent for publication}

The Publisher has the Author's permission to publish the relevant Contribution.

\section{Competing interests}

Authors declare no conflict of interest to this study.

Received: 14 October 2020 Accepted: 30 October 2020

Published online: 12 November 2020

\section{References}

1. Afridi R, Lee $W H$, Suk K. Microglia gone awry: linking Immunometabolism to Neurodegeneration. Front Cell Neurosci. 2020;14:246.

2. Bailey CC, Zhong G, Huang IC, Farzan M. IFITM-family proteins: the Cell's first line of antiviral defense. Annu Rev Virol. 2014;1:261-83.

3. Baruch K, Deczkowska A, David E, Castellano JM, Miller O, Kertser A, Berkutzki T, Barnett-ltzhaki Z, Bezalel D, Wyss-Coray T, et al. Aging. Aginginduced type I interferon response at the choroid plexus negatively affects brain function. Science. 2014;346:89-93.

4. Boelen E, Stassen FR, van der Ven AJ, Lemmens MA, Steinbusch HP, Bruggeman CA, Schmitz C, Steinbusch HW. Detection of amyloid beta aggregates in the brain of BALB/C mice after chlamydia pneumoniae infection. Acta Neuropathol. 2007;114:255-61.

5. Bourgade K, Dupuis G, Frost EH, Fülöp T. Anti-viral properties of amyloid- $\beta$ peptides. J Alzheimers Dis. 2016;54:859-78.

6. Brothers HM, Gosztyla ML, Robinson SR. The physiological roles of amyloid$\beta$ peptide hint at new ways to treat Alzheimer's disease. Front Aging Neurosci. 2018;10:118.

7. Cao W, Zheng H. Peripheral immune system in aging and Alzheimer's disease. Mol Neurodegener. 2018;13:51.

8. Desai TM, Marin M, Chin CR, Savidis G, Brass AL, Melikyan GB. IFITM3 restricts influenza a virus entry by blocking the formation of fusion pores following virus-endosome hemifusion. PLoS Pathog. 2014;10:e1004048.

9. Eimer WA, Vijaya Kumar DK, Navalpur Shanmugam NK, Rodriguez AS, Mitchell T, Washicosky KJ, György B, Breakefield XO, Tanzi RE, Moir RD. Alzheimer's disease-associated $\beta$-amyloid is rapidly seeded by Herpesviridae to protect against brain infection. Neuron. 2018;99:56-63 e53.

10. Feeley EM, Sims JS, John SP, Chin CR, Pertel T, Chen LM, Gaiha GD, Ryan BJ, Donis RO, Elledge SJ, et al. IFITM3 inhibits influenza a virus infection by preventing cytosolic entry. PLoS Pathog. 2011;7:e1002337.

11. Felsky D, Patrick E, Schneider JA, Mostafavi S, Gaiteri C, Patsopoulos N, Bennett DA, De Jager PL. Polygenic analysis of inflammatory disease variants and effects on microglia in the aging brain. Mol Neurodegener. 2018;13:38. 
12. Frost GR, Jonas LA, Li YM. Friend, foe or both? Immune activity in Alzheimer's disease. Front Aging Neurosci. 2019;11:337.

13. Gosztyla ML, Brothers HM, Robinson SR. Alzheimer's amyloid- $\beta$ is an antimicrobial peptide: a review of the evidence. J Alzheimers Dis. 2018;62: 1495-506.

14. Gratuze M, Leyns CEG, Holtzman DM. New insights into the role of TREM2 in Alzheimer's disease. Mol Neurodegener. 2018;13:66.

15. Guo T, Zhang D, Zeng Y, Huang TY, Xu H, Zhao Y. Molecular and cellular mechanisms underlying the pathogenesis of Alzheimer's disease. Mol Neurodegener. 2020;15:40.

16. Hur JY, Frost GR, Wu X, Crump C, Pan SJ, Wong E, Barros M, Li T, Nie P, Zhai Y, Wang JC, TcW J, Guo L, McKenzie A, Ming C, Zhou X, Wang M, Sagi Y, Renton AE, Esposito BT, Kim Y, Sadleir KR, Trinh I, Rissman RA, Vassar R, Zhang B, Johnson DS, Masliah E, Greengard P, Goate A, Li YM. The innate immunity protein IFITM3 modulates $\gamma$-secretase in Alzheimer's disease. Nature. 2020;586(7831):735-40. https://doi.org/10.1038/s41586-020-2681-2. Epub 2020 Sep 2. PMID: 32879487.

17. Ishida N, Ishihara Y, Ishida K, Tada H, Funaki-Kato Y, Hagiwara M, Ferdous T, Abdullah M, Mitani A, Michikawa M, et al. Periodontitis induced by bacterial infection exacerbates features of Alzheimer's disease in transgenic mice. NPJ Aging Mech Dis. 2017;3:15.

18. Jin X, Yamashita T. Microglia in central nervous system repair after injury. J Biochem. 2016;159:491-6.

19. John SP, Chin CR, Perreira JM, Feeley EM, Aker AM, Savidis G, Smith SE, Elia $A E$, Everitt AR, Vora $M$, et al. The CD225 domain of IFITM3 is required for both IFITM protein association and inhibition of influenza a virus and dengue virus replication. J Virol. 2013;87:7837-52.

20. Keren-Shaul H, Spinrad A, Weiner A, Matcovitch-Natan O, Dvir-Szternfeld R, Ulland TK, David E, Baruch K, Lara-Astaiso D, Toth B, et al. A unique microglia type associated with restricting development of Alzheimer's disease. Cell. 2017;169:1276-90.

21. Klein HU, McCabe C, Gjoneska E, Sullivan SE, Kaskow BJ, Tang A, Smith RV Xu J, Pfenning AR, Bernstein BE, et al. Epigenome-wide study uncovers large-scale changes in histone acetylation driven by tau pathology in aging and Alzheimer's human brains. Nat Neurosci. 2019;22:37-46.

22. Lin YT, Seo J, Gao F, Feldman HM, Wen HL, Penney J, Cam HP, Gjoneska E, Raja WK, Cheng J, et al. APOE4 causes widespread molecular and cellular alterations associated with Alzheimer's disease phenotypes in human iPSCderived brain cell types. Neuron. 2018;98:1141-54 e1147.

23. Little CS, Joyce TA, Hammond CJ, Matta H, Cahn D, Appelt DM, Balin BJ. Detection of bacterial antigens and Alzheimer's disease-like pathology in the central nervous system of BALB/C mice following intranasal infection with a laboratory isolate of chlamydia pneumoniae. Front Aging Neurosci. 2014;6:304.

24. Lu J, Pan Q, Rong L, He W, Liu SL, Liang C. The IFITM proteins inhibit HIV-1 infection. J Virol. 2011;85:2126-37.

25. Mathews S, Branch Woods A, Katano I, Makarov E, Thomas MB, Gendelman HE, Poluektova LY, Ito M, Gorantla S. Human Interleukin-34 facilitates microglia-like cell differentiation and persistent HIV-1 infection in humanized mice. Mol Neurodegener. 2019;14:12

26. Mathys H, Adaikkan C, Gao F, Young JZ, Manet E, Hemberg M, De Jager PL, Ransohoff RM, Regev A, Tsai LH. Temporal tracking of microglia activation in Neurodegeneration at single-cell resolution. Cell Rep. 2017;21:366-80.

27. Moir RD, Lathe R, Tanzi RE. The antimicrobial protection hypothesis of Alzheimer's disease. Alzheimers Dement. 2018;14:1602-14.

28. Oakley H, Cole SL, Logan S, Maus E, Shao P, Craft J, Guillozet-Bongaarts A, Ohno M, Disterhoft J, Van EL, et al. Intraneuronal beta-amyloid aggregates, neurodegeneration, and neuron loss in transgenic mice with five familial Alzheimer's disease mutations: potential factors in amyloid plaque formation. J Neurosci. 2006;26:10129-40.

29. Pan XD, Zhu YG, Lin N, Zhang J, Ye QY, Huang HP, Chen XC. Microglial phagocytosis induced by fibrillar beta-amyloid is attenuated by oligomeric betaamyloid: implications for Alzheimer's disease. Mol Neurodegener. 2011;6:45.

30. Park J, Wetzel I, Marriott I, Dreau D, D'Avanzo C, Kim DY, Tanzi RE, Cho H. A $3 \mathrm{D}$ human triculture system modeling neurodegeneration and neuroinflammation in Alzheimer's disease. Nat Neurosci. 2018;21:941-51.

31. Peng T, Hang HC. Site-specific bioorthogonal labeling for fluorescence imaging of intracellular proteins in living cells. J Am Chem Soc. 2016;138: 14423-33.

32. Perreira JM, Chin CR, Feeley EM, Brass AL. IFITMs restrict the replication of multiple pathogenic viruses. J Mol Biol. 2013;425:4937-55.
33. Pimenova AA, Raj T, Goate AM. Untangling genetic risk for Alzheimer's disease. Biol Psychiatry. 2018:83:300-10.

34. Prior M, Shi Q, Hu X, He W, Levey A, Yan R. RTN/Nogo in forming Alzheimer's neuritic plaques. Neurosci Biobehav Rev. 2010;34:1201-6.

35. Sällman Almén M, Bringeland N, Fredriksson R, Schiöth HB. The dispanins: a novel gene family of ancient origin that contains 14 human members. PLoS One. 2012;7:e31961.

36. Shi Y, Holtzman DM. Interplay between innate immunity and Alzheimer disease: APOE and TREM2 in the spotlight. Nat Rev Immunol. 2018;18:759-72.

37. Soscia SJ, Kirby JE, Washicosky KJ, Tucker SM, Ingelsson M, Hyman B, Burton MA, Goldstein LE, Duong S, Tanzi RE, et al. The Alzheimer's diseaseassociated amyloid beta-protein is an antimicrobial peptide. PLoS One. 2010;5:e9505.

38. Spence JS, He R, Hoffmann HH, Das T, Thinon E, Rice CM, Peng T, Chandran $\mathrm{K}$, Hang HC. IFITM3 directly engages and shuttles incoming virus particles to lysosomes. Nat Chem Biol. 2019;15:259-68.

39. Tanaka S, Nagashima H. Establishment of an Alzheimer's disease model with latent herpesvirus infection using PS2 and Tg2576 double transgenic mice. Exp Anim. 2018;67:185-92

40. Thome AD, Faridar A, Beers DR, Thonhoff JR, Zhao W, Wen S, Pascual B, Masdeu JC, Appel SH. Functional alterations of myeloid cells during the course of Alzheimer's disease. Mol Neurodegener. 2018;13:61.

41. Torres L, Robinson SA, Kim DG, Yan A, Cleland TA, Bynoe MS. Toxoplasma gondii alters NMDAR signaling and induces signs of Alzheimer's disease in wild-type, C57BL/6 mice. J Neuroinflammation. 2018;15:57.

42. Wakim LM, Gupta N, Mintern JD, Villadangos JA. Enhanced survival of lung tissue-resident memory $\mathrm{CD}^{+} \mathrm{T}$ cells during infection with influenza virus due to selective expression of IFITM3. Nat Immunol. 2013;14:238-45.

43. Wu X, Dao Thi VL, Huang Y, Billerbeck E, Saha D, Hoffmann HH, Wang Y, Silva LAV, Sarbanes $S$, Sun T, et al. Intrinsic immunity shapes viral resistance of stem cells. Cell. 2018;172:423-38 e425.

\section{Publisher's Note}

Springer Nature remains neutral with regard to jurisdictional claims in published maps and institutional affiliations.
Ready to submit your research? Choose BMC and benefit from:

- fast, convenient online submission

- thorough peer review by experienced researchers in your field

- rapid publication on acceptance

- support for research data, including large and complex data types

- gold Open Access which fosters wider collaboration and increased citations

- maximum visibility for your research: over $100 \mathrm{M}$ website views per year

At $\mathrm{BMC}$, research is always in progress.

Learn more biomedcentral.com/submissions 